\title{
USING ACTION RESEARCH FOR CURRICULUM DEVELOPMENT AND IMPROVING THE LEARNING EXPERIENCE: A CASE STUDY
}

\author{
A. Oksiutycz* \\ e-mail: aoksiutycz@uj.ac.za \\ C. Azionya* \\ e-mail: cazionya@uj.ac.za \\ *Department of Strategic Communication \\ University of Johannesburg \\ Johannesburg, South Africa
}

\section{ABSTRACT}

The need to bridge the gap between theory and praxis has necessitated the inclusion of contextbased knowledge in university education that reflects the complexity of real life and grapples meaningfully with real world challenges. This has led to the inclusion of authentic learning practices in curricula and an application of new teaching methods to achieve high quality learning, characterised by relevance to students and their future work environments. This article discusses the action research which became a fundation for developing an applied module for a new Strategic Communication degree at a South African university. The objective of the project was to ensure that the course provides relevant skills and competencies, creates opportunities for the application of disciplinary knowledge within a social context and enhances the student's learning experience by using project-based teaching. This reflective process culminated in the development of a curriculum for the applied second year modules in the BA Strategic Communication degree.

Keywords: authentic learning, projects-based teaching, deep learning, interdisciplinary communities, action research, strategic communication, marketing communication, disciplinary convergence

\section{INTRODUCTION}

The gap between undergraduate university education and real world practice is well documented (Ardley 2006; Clark, Gray and Mearman 2006; Stein, Isaacs and Andrews 2004; Stringfellow, Ennis, Brennan and Harke 2006; Waker, Hanson, Nelson and Fisher 1998). The need to bridge the gap between theory and praxis has necessitated the inclusion of contextbased knowledge in university education that reflects the complexity of real life and grapples meaningfully with real world challenges. In 2012, the Department of Strategic Communication at the University of Johannesburg embarked on the development of a new curriculum for 
Corporate Communication and Marketing Communication courses, in response to the changing requirements of the industry, focusing on the application of authentic learning practices as a teaching method to achieve high quality learning, characterised by relevance to students and their future work environments.

This article discusses the action research that guided the development of the curriculum for a core applied study module for the BA Strategic Communication (Corporate) and BA Strategic Communication (Marketing) degrees, based on the three interrelated concepts: project-based teaching, authentic learning, and interdisciplinary communities of learning. In this article we use the word interdisciplinary in a broad sense. We acknowledge that both marketing and corporate communication as well as graphic design belong to the same industry. However, in terms of university education in South Africa, graphic design, marketing and corporate communication are perceived to be distinct disciplines, situated in different fields and drawing from different theoretical traditions. At South African universities these specialisations are almost invariably situated in different faculties. Graphic Design qualifications are typically housed in the Arts or Humanities faculties; Corporate Communication and related qualifications such as Public Relations are affiliated either to the Humanities or the Management Science faculty, and Marketing is usually attached to the Faculty of Management and/or Economic Sciences.

The objective of this research conducted over a period of 4 years was to develop teaching practices that enhance the student's learning experience and the acquisition of specific applied skills, as well as the application of broad disciplinary knowledge using a problem-based project. This reflective process culminated in the development of a curriculum for the applied second year subjects in the BA Strategic Communication degree which integrates learning experiences from each teaching cycle. This article focuses on the development of the curriculum and a teaching approach for a second year semester module.

\section{DISCIPLINARY CONVERGENCE IN MARKETING AND CORPORATE COMMUNICATION}

The main drive behind the development of the new curriculum was the increasingly blurred lines between Marketing, Public Relations and Corporate Communication. The need for an interdisciplinary approach to practice-based instruction is supported by the everyday experience of practitioners, as well as the evidence from academic literature from both the field of Marketing and Corporate Communication (Ardley 2006; Clark, Gray and Mearman 2006; Stein, Isaacs and Andrews 2004; Stringfellow et al. 2006; Waker et al. 1998). 
Although Marketing and Corporate Communication have different traditions, Christensen, Morsing and Cheney (2008), as well as Hutton (2010) observe the trend towards communication convergence, the impact of which on the field of Marketing and Corporate Communication cannot be ignored. Communication convergence involves blurring boundaries and redefining different fields of communication, specifically Marketing Communication, Public Relations (PR) and Corporate Communication - a tendency which is even more evident in the development of various digital platforms of communication (Scott 2009). The notion of communication integration has been present in the fields of Marketing, Corporate Communication and PR for many years (Cornelissen 2011; Duncan and Moriarty 1998; Hallahan 2007). Hence the need arises to abandon the disciplinary silos and develop a curriculum that encompasses knowledge and skills relevant not only to the current industry practice but also to the broader society, using an approach that blends authentic learning, interdisciplinary communities of practice and project-based teaching. Bader and Zotter (2012) assert that the failure to address complex societal issues comes from the fact that these questions are often dealt with by a single discipline, while complex problems and questions require interdisciplinary collaboration.

Despite the calls for the inclusion of interdisciplinary approaches to education, these aspirations have remained rhetorical (Warburton 2003, 44). Universities tend to teach abstract and decontextualised concepts (Herrington and Oliver 2000, 23) in disciplinary silos (Waker et al. 1998, 804). Consequently, students end up acquiring specific terminology, skills and attitudes rooted in the particular disciplinary approaches which shape the ways in which they view and solve problems by applying specific discipline-based 'lenses' rather than seeking holistic solutions for business or social problems. This analysis is not a criticism of the content of the courses but rather the acknowledgement of practical reasons why discipline-based approaches prevail; from the convenience of allocating tasks to faculty staff, to university academic structures grouped according to relatively narrow fields, to the founding models in South African education, where different faculties and departments compete for financial viability. Within this context this project aimed at overcoming these limitations, albeit on a relatively small scale within one module taught to the second year students at the University of Johannesburg. In this case the aim was to improve the teaching methods and learning experience of the students and the development of the curriculum for a new Applied Marketing and Corporate Communication module (a semester course) within the BA Strategic Communication course. 


\section{METHOD}

Action research was used in this study, because action research is typically used to improve the communities where the researchers practice (Brydon-Miller, Greenwood and Maguire 2003). Action research is a philosophy which requires researchers to reflect on their activity. It is also a research approach which combines different research methods. The process of action research requires a repetition of a series of steps including situational analyses, planning, the implementation of planned action steps, observation and reflection (Costello 2003; Kember 2005; Saunders, Lewis and Thornhill 2003). Applied to an educational setting, action research can be cyclical and continual, where educators systematically reflect on their practice and make changes to their instruction, based on the findings aimed at improving their teaching practices (Costello 2003; Little 2012). In this case the researchers, who are also lecturers in the programme, envisaged incorporating learning experiences from each cycle to streamline, optimise and innovate the curriculum and its delivery. The research conducted at each cycle was designed to identify areas for improvement and best practice. The key learnings from each cycle are covered in the discussion.

The current article reports on the findings of the four cycles of the project: the first conducted in 2012, the second conducted in 2013, the third in 2014 and the fourth in 2015. The population of the study comprised 1001 second year students in the Department of Strategic Communication from 2012 to 2015. Data from the BA Strategic Communication students was collected using a mixed method approach. In the first cycle, 290 students, working in 41 teams (communities of learning) took part in the project. A four point Likert scale questionnaire, where 1 is strongly disagree, 2 is disagree, 3 is agree and 4 is strongly agree, was developed in order to establish the students' perceptions about various aspects of the module. The questionnaires were given to all students present in class at the end of the semester. In the first cycle, 52 questionnaires were completed by the Strategic Communication students.

In addition, the researchers conducted 14 interviews, designed to gain a deeper understanding of students' opinions about the learning that took place throughout the project. During the second cycle 249 students worked in 31 teams. From that cohort we collected 94 questionnaires from the Strategic Communication students. In the third cycle 237 students worked in 38 teams. In the third cycle in 2014 a focus group was conducted with some of the top achievers, laureates of the South African Direct Marketing Industry Award (the Assegai Awards) in a student category. In the fourth cycle we had 225 students working in 34 teams. That year, two focus groups were conducted with the students who progressed to the final stage of the project, namely those who collaborated with the Graphic Design students. 
The results from the surveys were analysed using descriptive statistics. The interviews and the focus groups were analysed using a thematic analysis approach. We also analysed the students pass rates and the marks for the individual assessments as a measure of the achievement of instructional goals. In addition, informal interviews with the representative of the Direct Marketing Association of South Africa (DMASA) regarding the content and the standard of the students' projects were also conducted, and feedback from the representatives of the 'client' organisations was also taken into account.

\section{SITUATIONAL ANALYSIS}

The reasons for initiating the research were multiple. Firstly, the lecturers reflected on their teaching practices and looked for ways to make the learning process more learner centred, more engaging, enjoyable and relevant to students and the changing work environment. Secondly, the development of important high order skills such as critical thinking skills, problem solving, creativity and a strategic mind-set were identified as important outcomes of the learning experience for students. Thirdly, crafting a learning experience that reflected the future world of work for students through interdisciplinary collaboration was of key importance as it is the norm in the strategic communication industry. Lastly, the importance of linking the theory and practice in terms of the curriculum was recognised, as university degrees fall short in the workintegrated learning component. Trends towards interdisciplinary approaches to learning, as well as disciplinary trends towards convergence in marketing and corporate communication led to the development of a new qualification at the University of Johannesburg (BA Strategic Communication), with updated curricula.

The authentic learning approach was at the centre of our teaching philosophy. Authentic learning is an approach aimed at assisting students to deal with the complexities of reality. The learning experience was designed to emulate the future work scenarios in two ways: through role playing and interdisciplinary collaboration. Authentic learning requires the lecturers to develop real world and relevant tasks which are sequential, aligned with each other and clearly leading to the desired learning outcomes (Meyers and McNulty 2008, 4). Furthermore, authentic learning requires a community of learning (Renzuli, Gentry and Reis 2004; Rule 2006) the client (or problem 'owner'), a set adviser and a time frame (Kozubska and McKenzie 2012, 148). In addition, the task should create the opportunity for examining the problem from a variety of perspectives, reflection, and should lead to a diversity of outcomes (McKenzie et al. 2002, 426).

While the use of authentic projects is not new, building the entire module curriculum 
around one interdisciplinary project is rare. We concur with (Powell 2007, 13) that projectbased teaching is a departure from classroom practices based on short isolated assessment. Instead, project-based teaching highlights the interconnectedness of different sections of the curriculum, promotes deep learning, integration of knowledge and develops in leaners a sense of responsibility for their own learning through their engagement with real life problems.

Group collaboration in communities of learning is an essential aspect of both authentic learning and project-based learning. It ensures that students are exposed to different perspectives and roles beyond their area of specialisation (Lombardi 2007, 3) to cultivate, sensitise and develop interdisciplinary thinking. A community of learning is defined as a system of relationships between people, the activities they are involved in, and the world (Ardley 2006, 209). Wenger and Wenger-Trayner (2015) identify a number of characteristics that communities of learning have such as: problem solving, information sharing, coordination and synergy between the members, discussing developments as the task progresses, identifying gaps and documenting work. The learning was facilitated through team teaching and coordinated by three lecturers from two different faculties: the Faculty of Humanities and the Faculty of Art, Design and Architecture (FADA). In addition, the students were also guided by industry mentors practitioners from DMASA.

\section{PLANNING AND IMPLEMENTATION OF AN INTERDISCIPLINARY LEARNING ENVIRONMENT}

Action research is not a linear process and therefore the research and practice are executed simultaneously. As innovations in the teaching practice were introduced, feedback was sought and lecturers continually reflected on their teaching. Each learning cycle analysed here took place over a period of one semester, during which the students, working in groups consisting of 5 to 8 students had to develop an integrated communication campaign for a specific real life 'client', a non-profit organisation in this case. During the period of 4 years in which this research was conducted, the lecturers cooperated with a non-profit organisation (the Organ Donor Foundation), an intergovernmental organisation (the International Organisation for Migration) and the UJ Faculty of Art, Design and Architecture (FADA), all of which provided authentic client briefs requiring the development of custom-made communication campaigns by the students for these clients.

The learning in this applied module was built around the planning and design of the communication campaign. The challenge in designing this component of the project was in incorporating various learning outcomes relevant to each qualification. Strategic 
Communication students were expected to learn such skills as interpreting the client brief, developing the campaign plan, campaign evaluation methods, basic research skills, market segmentation methods, writing research reports, selecting the appropriate media channels, budgeting, writing a creative brief, PowerPoint presentation skills and pitching the campaign concept to the client. The learning outcomes of the Graphic Design students focused on research, interpreting the creative brief and developing commercial graphic design executions and presenting their ideas to the client.

Using a limited budget, the campaigns had to factor in South Africa's multicultural and socio-economic diversity using the principles of interactive and direct marketing. For example, in the first cycle the students dealt with the legally and socially complex issue of organ donation. In the second cycle, students were required to develop an integrated brand communication campaign for one of the university faculties aimed at increasing the number of top-quality applicants, without losing the current loyal support base for the courses offered by the faculty. In the third cycle, the International Organisation for Migration (IOM) requested that the students develop a twelve month national awareness raising campaign around the issue of trafficking in persons in South Africa within the broad IOM strategy of prevention, protection and prosecution on a budget of one million US dollars. In the fourth cycle students had to develop a campaign aimed at presenting a positive image of foreign migrants in South Africa in the current social context of violence against migrants from other African countries.

In all cases, the briefs were purposefully ill-defined and required students to correctly identify and frame the central problem and formulate an appropriate response within the parameters of available resources. The tasks could not be completed on an individual basis but were executed as a multi-skilled collective to reflect the world of work, characterised by complex problems tackled by teams incorporating diverse skills, ranks and socio-cultural backgrounds. Working in such groups required students to use language and social discourse to make sense of the world around them. This collaborative context allowed students to reflect on their learning as individuals, as well as members of a group.

\section{OBSERVATION AND REFLECTION}

The results from the student surveys conducted in the first two cycles, presented in Table 1, indicate that overall the students found the learning experience to be positive. This was supported by the comments from the interviews. The students acknowledged that they acquired new knowledge of other specialisations. Respondent C1R2 asserted: 'I learned a lot of new skills that are useful'. While C1R9 noted: 'I have learnt not to be over-creative but to be able 
to relate to the target audience'. The majority of the students agreed that this particular project was more challenging than most of the other classroom projects; nevertheless, they enjoyed it and they were of the opinion that other second-year students should have the opportunity to do a similar project. The project also induced some self-reflection on the part of students. For instance, C3R1 said: 'You learn about your own weaknesses as well'. C3R5 added: 'We are seeing the value in what we do [...] and an opportunity to experience how everything comes together. It makes you see why we constantly hear about collaboration.' On their ability to deal with the ambiguous tasks: 'We define the problem, we define the missing link' said C3R5.

Table 1: The survey among Strategic Communication students 2012 and 2013 - descriptive statistics

\begin{tabular}{|c|c|c|c|c|c|c|c|c|c|c|}
\hline \multirow[b]{2}{*}{ Question } & \multicolumn{5}{|c|}{ Cycle 1 (2012) } & \multicolumn{5}{|c|}{ Cycle 2 (2013) } \\
\hline & Mean & $\begin{array}{l}\text { Media } \\
\mathrm{n}\end{array}$ & Mode & $\begin{array}{l}\text { Stand } \\
\text { Dev }\end{array}$ & $\mathbf{n}$ & Mean & $\begin{array}{l}\text { Media } \\
\mathrm{n}\end{array}$ & Mode & $\begin{array}{l}\text { Stand } \\
\text { dev }\end{array}$ & $\mathbf{n}$ \\
\hline $\begin{array}{l}\text { The project broadened my } \\
\text { knowledge perspective }\end{array}$ & 3.35 & 3.00 & 3.00 & 0.52 & 52 & 3.14 & 3.00 & 3.00 & 0.82 & 94 \\
\hline $\begin{array}{l}\text { The project helped me to } \\
\text { understand my role as a strategic } \\
\text { communicator }\end{array}$ & 3.33 & 4.00 & 3.00 & 0.68 & 52 & 2.73 & 3.00 & 3.00 & 1.01 & 94 \\
\hline $\begin{array}{l}\text { The project helped me to } \\
\text { understand the similarities between } \\
\text { corporate and marketing } \\
\text { communication }\end{array}$ & 2.83 & 3.00 & 3.00 & 0.96 & 52 & 2.78 & 3.00 & 3.00 & 0.84 & 92 \\
\hline $\begin{array}{l}\text { The project gave me better } \\
\text { understanding of the work of the } \\
\text { creative (designers) in } \\
\text { communication campaigns }\end{array}$ & 3.29 & 3.00 & 3.00 & 0.78 & 52 & 3.20 & 3.00 & 3.00 & 0.80 & 94 \\
\hline $\begin{array}{l}\text { The project gave me a good } \\
\text { understanding of the research } \\
\text { process }\end{array}$ & 3.42 & 3.50 & 4.00 & 0.64 & 52 & 3.41 & 4.00 & 4.00 & 0.76 & 94 \\
\hline $\begin{array}{l}\text { The project taught me how to deal } \\
\text { with group dynamics }\end{array}$ & 3.35 & 3.00 & 3.00 & 0.68 & 52 & 3.29 & 3.00 & 3.00 & 0.76 & 94 \\
\hline $\begin{array}{l}\text { The project challenged me to think } \\
\text { creatively }\end{array}$ & 3.54 & 4.00 & 4.00 & 0.54 & 52 & 3.42 & 4.00 & 4.00 & 0.73 & 94 \\
\hline $\begin{array}{l}\text { I found working with a live client } \\
\text { brief challenging }\end{array}$ & 3.23 & 3.00 & 4.00 & 0.85 & 52 & 3.00 & 3.00 & 4.00 & 0.99 & 94 \\
\hline $\begin{array}{l}\text { The project gave me an insight into } \\
\text { my future job }\end{array}$ & 2.92 & 3.00 & 3.00 & 0.77 & 52 & 3.03 & 3.00 & 3.00 & 0.90 & 92 \\
\hline $\begin{array}{l}\text { I learnt from other group members } \\
\text { during the project }\end{array}$ & 3.10 & 3.00 & 3.00 & 0.78 & 52 & 3.02 & 3.00 & 3.00 & 0.87 & 93 \\
\hline $\begin{array}{l}\text { The objectives of the project were } \\
\text { clear }\end{array}$ & 3.23 & 3.00 & 3.00 & 0.70 & 52 & 2.89 & 3.00 & 3.00 & 0.87 & 94 \\
\hline $\begin{array}{l}\text { Students were given enough time to } \\
\text { complete the project }\end{array}$ & 3.17 & 3.00 & 4.00 & 0.88 & 52 & 3.16 & 3.00 & 3.00 & 0.78 & 94 \\
\hline $\begin{array}{l}\text { The workshops conducted by DMA } \\
\text { professionals were helpful }\end{array}$ & 2.72 & 3.00 & 3.00 & 0.99 & 52 & 2.82 & 3.00 & 3.00 & 0.85 & 91 \\
\hline $\begin{array}{l}\text { The lecturers gave a constructive } \\
\text { feedback after the presentations }\end{array}$ & 3.19 & 3.00 & 4.00 & 0.86 & 52 & 2.76 & 3.00 & 2.00 & 1.03 & 94 \\
\hline $\begin{array}{l}\text { I enjoyed working with students } \\
\text { from other degrees }\end{array}$ & 2.83 & 3.00 & 3.00 & 1.08 & 52 & 2.73 & 3.00 & 4.00 & 1.08 & 94 \\
\hline $\begin{array}{l}\text { The project was more challenging } \\
\text { than other class projects }\end{array}$ & 3.00 & 3.00 & 4.00 & 0.94 & 52 & 3.10 & 3.00 & 3.00 & 0.78 & 94 \\
\hline I enjoyed the project & 2.90 & 3.00 & 3.00 & 0.90 & 52 & 2.90 & 3.00 & 3.00 & 0.97 & 94 \\
\hline $\begin{array}{l}\text { The project gave me some insight } \\
\text { into the industry }\end{array}$ & 2.98 & 3.00 & 3.00 & 0.73 & 51 & 3.04 & 3.00 & 3.00 & 0.81 & 94 \\
\hline $\begin{array}{l}\text { Leaning through practice is more } \\
\text { effective then learning in class }\end{array}$ & 3.54 & 4.00 & 4.00 & 0.67 & 52 & 3.24 & 3.00 & 3.00 & 0.79 & 94 \\
\hline Future 2nd year Strategic & 3.25 & 3.00 & 4.00 & 0.90 & 52 & 3.13 & 4.00 & 4.00 & 1.08 & 94 \\
\hline
\end{tabular}




\begin{tabular}{|c|c|c|c|c|c|c|c|c|c|c|}
\hline \multirow[b]{2}{*}{ Question } & \multicolumn{5}{|c|}{ Cycle 1 (2012) } & \multicolumn{5}{|c|}{ Cycle 2 (2013) } \\
\hline & Mean & $\begin{array}{l}\text { Media } \\
\text { n }\end{array}$ & Mode & $\begin{array}{l}\text { Stand } \\
\text { Dev }\end{array}$ & $\mathbf{n}$ & Mean & $\begin{array}{l}\text { Media } \\
\mathrm{n}\end{array}$ & Mode & $\begin{array}{l}\text { Stand } \\
\text { dev }\end{array}$ & $\mathbf{n}$ \\
\hline \multicolumn{11}{|l|}{$\begin{array}{l}\text { Communication students should be } \\
\text { given a similar project }\end{array}$} \\
\hline \multicolumn{11}{|c|}{ Questions used only in 2013 questionnaire } \\
\hline $\begin{array}{l}\text { The project taught me how to } \\
\text { present my ideas to a client }\end{array}$ & & & & & & 3.18 & 3.00 & 3.00 & 0.84 & 94 \\
\hline $\begin{array}{l}\text { The project required me to apply my } \\
\text { prior subject knowledge }\end{array}$ & & & & & & 3.23 & 3.00 & 3.00 & 0.81 & 94 \\
\hline $\begin{array}{l}\text { The project taught me how to solve } \\
\text { problems in a group context }\end{array}$ & & & & & & 3.22 & 3.00 & 3.00 & 0.71 & 94 \\
\hline $\begin{array}{l}\text { Most group members were } \\
\text { available for meetings }\end{array}$ & & & & & & 2.87 & 3.00 & 3.00 & 0.95 & 94 \\
\hline $\begin{array}{l}\text { The final presentation was truly a } \\
\text { team effort }\end{array}$ & & & & & & 2.92 & 3.00 & 4.00 & 1.07 & 94 \\
\hline $\begin{array}{l}\text { The project challenged me to think } \\
\text { strategically }\end{array}$ & & & & & & 3.20 & 3.00 & 4.00 & 0.82 & 93 \\
\hline $\begin{array}{l}\text { I feel working in interdisciplinary } \\
\text { teams is beneficial }\end{array}$ & & & & & & 3.15 & 3.00 & 4.00 & 0.86 & 92 \\
\hline $\begin{array}{l}\text { The project has given me the skills } \\
\text { to work effectively in an } \\
\text { interdisciplinary group }\end{array}$ & & & & & & 3.09 & 3.00 & 3.00 & 0.77 & 93 \\
\hline $\begin{array}{l}\text { I enjoyed working with the graphic } \\
\text { design students }\end{array}$ & & & & & & 2.97 & 3.00 & 4.00 & 1.00 & 94 \\
\hline
\end{tabular}

Authentic learning aims to connect student learning to real world problems and contexts. Therefore, learning about the social issues the students were tackling was an important contribution to their learning and engagement. According to C1R5, 'It was hard at first because it was something new to me, I didn't know a lot about organ donations and the number of lives one person can save'. C1R13 remarked: 'I learned a lot about the Organ Donor Foundation and I enjoyed the experience although it was stressful too'. In the true spirit of authentic learning there were many examples of the students taking their findings to their communities. For example, one of the groups from cycle 3 participated in a phone-in programme on a community radio station about the dangers of human trafficking. And after completing the project on migration, C44 admitted: 'I was embarrassed about how my community thinks about migrants'.

Working in interdisciplinary teams presented both challenges and opportunities for growth. Respondent C1R6 noted: 'It's stressful because we came from different courses, so ideas clash'. But others regarded the experience as positive: C1R7 saw it as strength: 'We can come with different knowledge and put it together'. Through role playing and interdisciplinary collaboration students were exposed to variegated roles and perspectives beyond their areas of specialisation. For instance, C1R11 remarked: 'I learned a lot from a graphic design perspective as well as a corporate communication perspective'. While C3R3 observed: 'It's about coming together and letting each other into each other's world'. The adaptation to group dynamics was a key finding and skill that students cultivated through their interactions. Respondent C1R1 said: 'I had a first-hand experience on [sic] how working in a team would be when I start 
working'. C1R4 concurred: 'Working in the team was quite interesting as I was able to understand the value of interaction within a team'. Respondent C1R3 added: 'I learnt to focus on everybody's strengths and skills in terms of what they can bring to the project. I learned the value of time.'

One of the aims of this research was to improve the organisational side of the project without being too prescriptive, and allowing the students to take greater responsibility for their own learning through encouraging them to engage in problem solving as a group. The results showed that students were generally satisfied with the organisation of the module and how the project was planned and administered. The students indicated that the parameters and objectives of the project were clear; and they had enough time to complete the project. C1R3 mentioned: 'At first we were bit confused but after applying [...] right everything went smooth'. CR15 revealed: 'The scope and objectives became clear, as the project developed, it came to life and we began believing in it'. Despite all the positive feedback, as lecturers we noticed some areas where improvement, additional reflection and follow-up was required.

\section{REFLECTION AND INTERVENTIONS}

As we researched and reflected on this project we introduced a number of interventions. For instance, the students highlighted some organisational difficulties related to group members being based on different campuses, such as transport, accessibility and communication. In cycle 4, to alleviate some of these logistical problems, we required that the groups utilise Google Drive and Survey Monkey as platforms that allow all group members to participate remotely to create and edit various documents.

We also identified some areas for improvement in terms of content delivery. For instance, the statement 'The project gave me a good understanding of the research process was answered overwhelmingly positive. Possibly it was because, for most of the students, it was the biggest and most comprehensive research project in scope undertaken to date. However, the lecturers saw a major skills disparity between the groups in the quality of data collection presentation and interpretation. As a result, we broke up the research process into smaller components and introduced a series of workshops where the specific aspects of research skills, such as data analysis or presentation of findings, were addressed. In the first two cycles, as revealed through the survey, the students did not always understand the content given by the industry experts and needed additional guidance in terms of applying the interactive and direct marketing theories appropriately. We then asked the guest industry lecturers to break the topics into very specific themes, so that the students could better understand the lecture context of the industry mentors. 
In the second cycle the students were less satisfied with the quality of the lecturer's feedback, which we attributed to the fact that in that particular year, due to the time and venue constraints, we could not spend as much time on feedback to each group as we would have liked to. The class size was the biggest challenge we faced as lecturers. Authentic learning is best realised in small groups, but at the University of Johannesburg a typical class size for the Strategic Communication degree at second year level is around 200 students.

It was established that the students' perception of the project was to a large extent influenced by group dynamics and how well the teams worked together. There were several issues affecting group dynamics. In the first two cycles, the Marketing Communication and Corporate Communication students had a different curricula focus and set of assessments. For instance, the Marketing Communication students did a similar client pitch project in the first year, while it was completely new to the Corporate Communication students and the Graphic Design Students. In order to eliminate the knowledge gaps, since 2014 the number of contact hours for the module has doubled and both Marketing and Corporate Communication cohorts are taught similar comprehensive content.

There were also misunderstandings about the role that each specialisation played in the project. Marketing and Corporate degree students, did not understand that the Graphic Design students were not merely the implementers, but creative contributors to the project. Furthermore, from the responses of the Graphic Design students it was noted that the Strategic Communication students did not appreciate that the Graphic Design students had very specific project outcomes as part of their assessment. Strategic Communication students also failed to grasp how time-consuming the designer's work is. So, the delays in producing the creative brief by the Strategic Communication students had repercussions for the quality of the graphic designers' work. In addition, in some cases the creative briefs prepared by the Strategic Communication students were poor.

The Graphic Design students, on the other hand, did not understand that the role of the Strategic Communication students was not only to research the problem, but to interpret the client brief and create a focused communication strategy aimed at specific audiences and supported by the relevant choice of touch points and budget. In the first two cycles the second year Corporate and Marketing degree students worked with the third-year (exit level) Graphic Design students. The third-year students felt that the second-year students were not as serious about the project as they were.

These issues were addressed in various ways: firstly, from 2013 onwards both Strategic Communication and the Graphic Design students were present during the client briefs; 
secondly, the lecturers had special presentations explaining the scope and nature of work done during the different phases and how these stages relate to the flow of work in a typical communication agency. In order to relieve the time pressure, the Graphic Design students worked on the project in the second semester, and in pairs (not individually) as of cycle 3. Since cycle 3, all the participating students were second year students. To address the quality of briefs presented by Strategic Communication students, the decision was made in cycle 4 that only the top 50 per cent of the creative briefs would be passed on for further development into the final stage by the Graphic Design students. In that way, working with the Graphic Design students became a kind of a reward for the Strategic Communication students.

\section{OUTCOMES - THE CURRICULUM}

The outcome of this research resulted in the development of a new curriculum. The incorporation of project-based teaching, interdisciplinary communities learning entrenched in the authentic learning philosophy approach has become a permanent curriculum feature for the second year Strategic Communication module. The outline of the module is summarised in the

Table 2.

Table 2: The teaching model for second-year Applied Strategic Communication

\begin{tabular}{|c|c|c|c|}
\hline The process & $\begin{array}{l}\text { Specific applied } \\
\text { skills }\end{array}$ & Academic content & Assessment \\
\hline $\begin{array}{l}\text { At the beginning of the } \\
\text { semester the client, identified } \\
\text { by the lecturers, briefs the } \\
\text { student about the } \\
\text { business/social problem they } \\
\text { need to solve through a } \\
\text { communication campaign the } \\
\text { students have to develop }\end{array}$ & $\begin{array}{l}\text { The interpretation of a } \\
\text { client brief }\end{array}$ & $\begin{array}{l}\text { Introduction to the } \\
\text { campaign planning } \\
\text { process } \\
\text { Understanding the } \\
\text { environmental and } \\
\text { business context }\end{array}$ & \\
\hline $\begin{array}{l}\text { Students are divided into } \\
\text { groups of } 5 \text { to } 6 \text { members } \\
\text { comprising both BA Strategic } \\
\text { Communication (Marketing) } \\
\text { and BA Strategic } \\
\text { Communication (Corporate) } \\
\text { students }\end{array}$ & $\begin{array}{l}\text { Problem research } \\
\text { Students conduct the } \\
\text { secondary research }\end{array}$ & $\begin{array}{l}\text { Introduction to various } \\
\text { applied research methods: } \\
\text { qualitative and } \\
\text { quantitative, data } \\
\text { interpretation and } \\
\text { presentation, writing } \\
\text { research reports }\end{array}$ & $\begin{array}{l}\text { Individual } \\
\text { assessment: writing } \\
\text { a short situation } \\
\text { analysis based on } \\
\text { secondary research }\end{array}$ \\
\hline $\begin{array}{l}\text { In groups, students conduct } \\
\text { primary research about the } \\
\text { problem }\end{array}$ & $\begin{array}{l}\text { Problem research and } \\
\text { target market research } \\
\text { Writing research } \\
\text { reports }\end{array}$ & $\begin{array}{l}\text { Market segmentation } \\
\text { methods }\end{array}$ & $\begin{array}{l}\text { Group assessment: } \\
\text { Compiling a } \\
\text { comprehensive } \\
\text { research report } \\
\text { based on secondary } \\
\text { and primary } \\
\text { research }\end{array}$ \\
\hline $\begin{array}{l}\text { Within interdisciplinary groups } \\
\text { students work on developing } \\
\text { the communication campaign } \\
\text { according to the client brief }\end{array}$ & $\begin{array}{l}\text { Developing the } \\
\text { campaign strategy }\end{array}$ & $\begin{array}{l}\text { Introduction to various } \\
\text { media and touch points: } \\
\text { traditional, digital and } \\
\text { hybrid media } \\
\text { Budgeting } \\
\text { Campaign evaluation } \\
\text { methods }\end{array}$ & \\
\hline
\end{tabular}




\begin{tabular}{|c|c|c|c|}
\hline The process & $\begin{array}{l}\text { Specific applied } \\
\text { skills }\end{array}$ & Academic content & Assessment \\
\hline $\begin{array}{l}\text { Semester test: theoretical } \\
\text { knowledge and reflection on } \\
\text { learning }\end{array}$ & & & $\begin{array}{l}\text { Individual } \\
\text { assessment: } \\
\text { semester test }\end{array}$ \\
\hline $\begin{array}{l}\text { Students present their ideas to } \\
\text { a panel of lecturers during the } \\
\text { last } 2 \text { weeks of the semester }\end{array}$ & $\begin{array}{l}\text { Pitching campaign } \\
\text { ideas to the client }\end{array}$ & $\begin{array}{l}\text { Power Point } \\
\text { presentations, public } \\
\text { speaking }\end{array}$ & $\begin{array}{l}\text { Group assessment: } \\
\text { Oral presentation to } \\
\text { the lecturers }\end{array}$ \\
\hline $\begin{array}{l}\text { Selected Marketing and } \\
\text { Communication student groups } \\
\text { are joined by the Graphic } \\
\text { Design students and jointly } \\
\text { develop the campaign to the } \\
\text { next stage }\end{array}$ & $\begin{array}{l}\text { Agency work flow, } \\
\text { writing a creative brief, } \\
\text { interpreting the } \\
\text { creative brief }\end{array}$ & $\begin{array}{l}\text { Graphic Design students } \\
\text { interpret the creative brief } \\
\text { and develop the creative } \\
\text { executions for the } \\
\text { campaign }\end{array}$ & $\begin{array}{l}\text { Individual or group } \\
\text { assessment: } \\
\text { Graphic designers' } \\
\text { work is assessed } \\
\text { and exhibited at the } \\
\text { department }\end{array}$ \\
\hline $\begin{array}{l}\text { The best combined groups } \\
\text { present their projects to the } \\
\text { client, as well as to industry } \\
\text { experts }\end{array}$ & $\begin{array}{l}\text { Pitching their ideas to } \\
\text { the client }\end{array}$ & $\begin{array}{l}\text { Power Point } \\
\text { presentations, oral } \\
\text { presentations }\end{array}$ & $\begin{array}{l}\text { Feedback received } \\
\text { from the client and } \\
\text { the industry experts }\end{array}$ \\
\hline $\begin{array}{l}\text { The best revised and improved } \\
\text { projects are entered into the } \\
\text { marketing and creative industry } \\
\text { competitions }\end{array}$ & & & \\
\hline
\end{tabular}

Although there are some core features of the module curriculum, the module is not rigid. Some elements may be added or removed depending on the nature of the client brief. For instance, if the brief requires a fundraising campaign then fundraising is included into the curriculum that year, if the campaign requires a direct marketing approach then more teaching time is spent on it. One important feature of authentic learning is the ability to share projects with the community or being able to apply them in practice. As a result of this reflective approach, the students' work won 9 marketing communication industry awards in the student category in 2012 and 2015. The Faculty of Arts Design and Architecture used the designs from several of the campaigns for its student recruitment drive in 2013. Elements from student campaigns for the counter-trafficking campaign were used by the IOM during human trafficking awareness week in 2014 and were used by the National Prosecuting Authority of South Africa as well as by the IOM mission in Mexico. Furthermore, the European Commission identified the 2014 project on human trafficking as one of the best practice cases used during a policy development intervention aimed at developing the new guidelines for counter-trafficking initiatives in the European Union. On average most students ( $n=898$ out of $n=1001$ students) achieved the desired study outcomes (average 89.75\% module pass rate) through all cycles.

\section{CONCLUSION}

This article reported on the action research used to develop a project-based teaching and interdisciplinary learning approach, based on the authentic learning philosophy for the core second year Applied Strategic Communication module at the University of Johannesburg. Teaching in this module is based on authentic activities designed to match the real world 
disciplinary-related tasks of practitioners, thereby making learning relevant to the social context in which students live, and fostering learner-centred learning in interdisciplinary groups. In line with the authentic learning philosophy, the learning is purposefully designed around authentic tasks set in 'meaningful and complex' Glatthorn $(1999,5)$ and 'ill-defined problems' Lombardi (2007, 3), or 'challenging investigations' (Luar 2013, 6). Authentic activities are designed to match the real world disciplinary-related tasks of practitioners as much as possible. This helped the students to contextualise and assimilate the content and develop the necessary skills they will use in their adult work experiences. The learning in the module is based on the issues relevant to students' lives, their communities or broader society to engender empathy, buy-in and social engagement. During the period in which the study was conducted, the students worked on projects related to student recruitment, organ donation, human trafficking and nation building. Students were exposed to different perspectives and roles beyond their area of specialisation (Lombardi 2007, 3) in order to cultivate, sensitise and develop interdisciplinary thinking and to simulate the professional working environment, thus bridging the gap between theory and practice.

The learning, conducted in an interdisciplinary community of practice based on the authentic learning philosophy, involving students from three different undergraduate qualifications, a national non-profit organisation, an intergovernmental organisation and industry experts, provided the students with a unique learning experience. The majority of the students achieved the desired study outcomes as indicated by the pass rates. The students recognised that they shared the disciplinary knowledge of all three specialisations. The students reported a positive learning experience in terms of acquiring specific skills, such as research, campaign planning and presentation skills, and due to its success, the model - with modifications - is also used in other modules offered by the Department of Strategic Communication. The new curriculum for BA Strategic Communication was introduced in 2013. The findings of the current research were taken into account and defined the content for the applied modules, Applied Corporate Communication and Applied Marketing Communication at the second year level, as of 2014.

\section{REFERENCES}

Ardley, B. 2006. Situated learning and marketing: Moving beyond the rational technical thought cage. Marketing Intelligence and Planning 24(3): 202- 17.

Bader, L. and V. Zotter. 2012. Interdisciplinary: Wishful thinking? Experiences at the University of Gratz. Multicultural Education and Technology Journal 6(3): 118-136.

Brydon-Miller, M., D. Greenwood and P. Maguire. 2003. Why action research? Action Research 1(1): 9-28. 
Christensen, L. T., M. Morsing and G. Cheney. 2008. Corporate communications, convention, complexity and critique. London: Sage.

Clarke, P., D. Gray and A. Mearman. 2006. The marketing curriculum and educational aims: Towards a professional education? Marketing Intelligence and Planning 24(3): 189-201.

Cornelissen, J. 2011. Corporate communication: A guide to theory and practice. 3rd Edition. Los Angeles: Sage.

Costello, P. J. M. 2003. Action research. London: Continuum.

Duncan, T. and S. Moriarty. 1998. Communication-based marketing model for managing relationship. Journal of Marketing 62(2): 1-13.

Glatthorn, A. A. 1999. Performance standards and authentic learning. NY: Eye on Education.

Hallahan, K. 2007. Integrated communication: Implications for public relations beyond excellence. In The future of excellence in public relations and communication management, ed. E. L. Tooth, 299-338. New York: Routledge.

Herington, J. and R. Oliver. 2000. An instructional design framework for authentic learning environments. Educational Technology Research and Development 48(3): 23-48.

Hutton, J. G. 2010. Defining the relationships between public relations and marketing: Public relations most important challenge. In The Sage handbook of public relations, ed. R. L. Heath, 501-522. London: Sage.

Kember, D. 2005. Action learning and action research. London: Kogan Page.

Kozubska, J. and B. MacKenzie. 2012. Differences and impacts through action learning. Action Learning: Research and Practice 9(2): 145-164.

Little, M. E. 2012. Action research and response to intervention: Bridging the discourse divide. The Educational Forum 76(1): 69-80.

Lombardi, M. M. 2007. Authentic learning for the 21st century: an overview. An Overview. Educause Learning Initiative. https://net.educause.edu/ir/library/pdf/eli3009.pdf

Luar, D. 2013. Authentic learning experiences: A real world approach to project based learning. NY, USA: Routledge.

McKenzie, A. D., C. K. Morgan, K. W. Cochrane, G. K. Watson and W. R. A. David. 2002. Authentic learning: What is it and what are the ideal curriculum conditions to cultivate it. In Higher Education Research and Development, 426-433.

Meyers, N. M. and D. D. Nulty. 2008. How to use (five) curriculum design principles to align authentic learning environments, assessments, students' approaches to thinking and learning outcomes. Assessment and Evaluation in Higher Education 34(5): 65-577. http://dx.doi.org/10.1080/ 02602930802226502

Powell, P. 2007. Arguments for implementing projects based learning. The Journal of Independent Teaching and Learning 2: 13-21.

Renzuli, J. S., M. Gentry and S. M. Reis. 2004. A time and a place for authentic learning. Educational Leadership 62(1): 73-77.

Rule, A. 2006. Editorial: The components of authentic learning. Journal of Authentic Learning 3(1): 110.

Scott, D. M. 2009. The new rules of marketing and PR. Hoboken, NJ: Wiley.

Saunders, M., P. Lewis and A. Thornhill. 2003. Research methods for business students. Harlow, England: Prentice Hall.

Stein, S., J. Isaacs and T. Andrews. 2004. Incorporating authentic learning experiences within a university course. Studies in Higher Education 29(2): 239-258.

Stringfellow, L., S. Ennis, R. Brennan and M. J. Harke. 2006. Mind the gap: The relevance of marketing education to marketing practice. Marketing Intelligence and Planning 24(3): 245-256. 
Waker, R. H., D. Hanson, L. Nelson and C. Fisher. 1998. A case for integrative multi-disciplinary marketing education. European Journal of Marketing 32(9/10): 803-812.

Warburton, K. 2003. Deep learning and education for sustainability. International Journal of Sustainability in Higher Education 4(1): 44-56.

Wenger, E. and B. Wegner-Trayner. 2015. Introduction to communities of practice. http://wengertrayner.com/introduction-to-communities-of-practice/ 